\title{
Acknowledgment to Reviewers of Journal of Zoological and Botanical Gardens in 2021
}

\section{JZBG Editorial Office}

Citation: JZBG Editorial Office. Acknowledgment to Reviewers of Journal of Zoological and Botanical Gardens in 2021. J. Zool. Bot. Gard. 2022, 3, 69-70. https://doi.org/ 10.3390/jzbg3010006

Published: 9 February 2022

Publisher's Note: MDPI stays neutral with regard to jurisdictional claims in published maps and institutional affiliations.

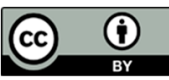

Copyright: $@ 2022$ by the author. Licensee MDPI, Basel, Switzerland. This article is an open access article distributed under the terms and conditions of the Creative Commons Attribution (CC BY) license (https://creativecommons.org/licenses/by/4.0/).
MDPI AG, St. Alban-Anlage 66, 4052 Basel, Switzerland

Rigorous peer-reviews are the basis of high-quality academic publishing. Thanks to the great efforts of our reviewers, Journal of Zoological and Botanical Gardens was able to maintain its standards for the high quality of its published papers. Thanks to the contribution of our reviewers, in 2021, the median time to first decision was 22.2 days and the median time to publication was 50 days. The editors would like to extend their gratitude and recognition to the following reviewers for their precious time and dedication, regardless of whether the papers they reviewed were finally published:

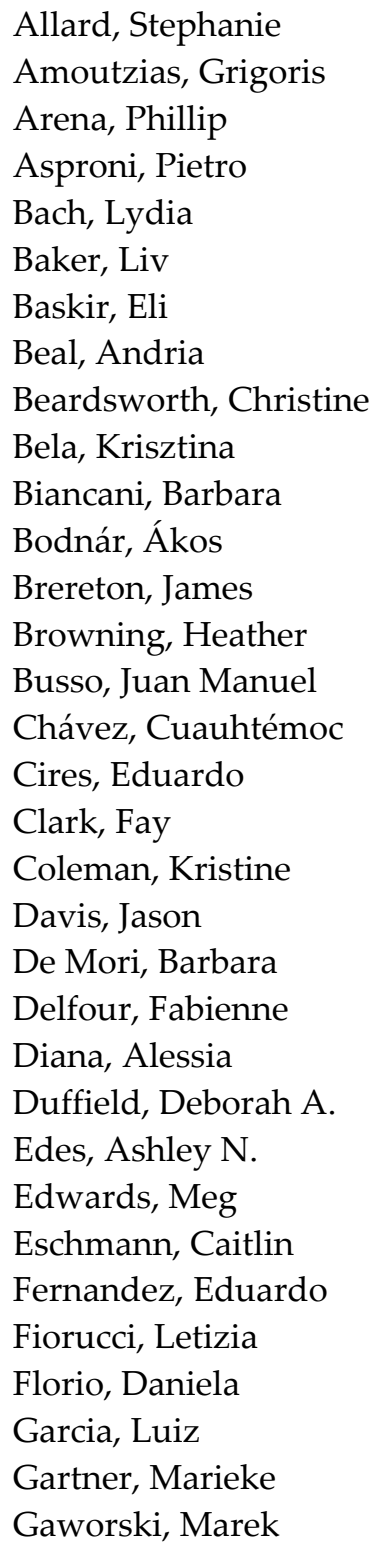


Osadchyi, Viacheslav

Palmer, Kaitlin

Parker, Matthew O.

Pastorino, Giovanni Quintavalle

Patrick, Patricia

Patterson-Kane, Emily G.

Pietroluongo, Guido

Price, Eluned

Rachinas-Lopes, Patrícia

Ramsay, Ruth

Ray, Jansen

Reljić, Slaven

Rendle, Jessica

Rocha, Luiene M.

Rose, Paul

Rosselló, Josep A.

Salas, Marina
Schick, Robert

Sepulveda, Néstor

Sergiel, Agnieszka

Soriano, Ana Isabel

Spooner, Sarah

Stannard, Hayley J.

Tomažič, Iztok

Tracey, Louise

Vaga, Merko

Vicino, Greg A.

Walker, Brian G.

Wierzbowska, Izabela

Williams, Ellen

Winship, Kelley

Witte, Carmel

Woods, Jocelyn M. 